\title{
IDENTITY, SYNONYMIES AND HOMONYNIES OF MINOR GRAPEVINE CULTIVARS MAINTAINED IN THE PORTUGUESE AMPELOGRAPHIC COLLECTION
}

\section{IDENTIFICAÇÃO, SINONÍMIAS E HOMONÍMIAS DE VARIEDADES MINORITÁRIAS PRESERVADAS NA COLEÇÃO AMPELOGRÁFICA PORTUGUESA}

\author{
Antonios Alifragkis ${ }^{1,2,7}$, Jorge Cunha ${ }^{3,4,7^{*}}$, Joana Pereira ${ }^{5}$, Pedro Fevereiro ${ }^{4,6}$, José E. J. Eiras Dias ${ }^{3}$ \\ ${ }^{1}$ Instituto Superior de Agronomia, Tapada da Ajuda, Lisboa, Portugal. \\ ${ }^{2}$ Aristotle University of Thessaloniki, Greece \\ ${ }^{3}$ Instituto Nacional de Investigação Agrária e Veterinária, Quinta d’Almoinha, Dois Portos, Portugal. \\ ${ }^{4}$ Universidade Nova de Lisboa, Instituto de Tecnologia Química e Biológica (ITQB), Green-it Unit, Portugal \\ ${ }^{5}$ Instituto Superior de Engenharia, Campus da Penha, Faro, Portugal. \\ ${ }^{6}$ Universidade de Lisboa, Faculdade de Ciências, Departamento de Biologia Vegetal, Portugal \\ ${ }^{7}$ both authors contributed equally to this work.
}

*corresponding author: Tel: +351261712106, e-mail: jorge.cunha@iniav.pt

(Received 29.01.2015. Accepted 20.07.2015)

\section{SUMMARY}

Nineteen SSR were used to genotype twenty eight accessions from Portugal, France, Greece, and Spain, preserved at the Portuguese National Ampelographic Collection (international code - PRT 051). Some of these accessions have never been genotyped and are minor, underused cultivars. Eight cases of synonymies and one case of homonymy were detected. The identification of synonyms in underused cultivars increases de possibility of obtaining adequate plant material for certification purposes and commercialization. The new unique genotypes identified in this work will be proposed for inclusion in the list of authorized cultivars for wine production in Portugal. No certified plant materials exist for these cultivars.

\section{RESUMO}

Dezanove SSR foram utilizados para genotipagem de vinte e oito acessos de Portugal, França, Grécia e Espanha, preservados na Coleção Ampelográfica Nacional (código internacional - PRT 051). Algumas destas cultivares nunca foram genotipadas e são cultivares minoritárias, subutilizadas. Oito casos de sinonímia e um caso de homonímia foram identificados. A identificação de sinonímias em cultivares subutilizadas aumenta a possibilidade de encontrar material vegetal adequado para fins de certificação e comercialização. Os novos genótipos únicos identificados neste trabalho serão propostos para inclusão na lista de cultivares autorizadas para produção de vinho em Portugal. Estes novos genótipos não possuem material vegetal certificado para propagação.

Key words: Minor Portuguese cultivars, genotyping, synonymies and homonymies, SSR.

Palavras-chave: Cultivares Portuguesas minoritárias, genotipagem, sinónimos e homónimos, SSR.

\section{INTRODUCTION}

High genetic variability allied to a long history and widespread area of cultivation, natural selection, natural crossing between cultivars, breeding and selection programs and the adaptation of cultivars to new environments, all are reasons for the precious and almost endless grapevine genetic diversity at our disposal. Viala and Vermorel, (1901-10) reported more than 24000 denominations of Vitis vinifera L, believed to correspond to about 8000 - 9000 concrete cultivars. In this context a meticulous identification and classification of the different cultivars is a difficult process. Synonyms (different names

\section{3}

This is an Open Access article distributed under the terms of the Creative Commons Attribution License

(http://creativecommons.org/licenses/by/4.0), which permits unrestricted use, distribution, and reproduction in any medium, provided the original work is properly cited. 
attributed to the same cultivar in different cultivation areas) and homonyms (attribution of the same name to different cultivars) found in different wine regions cause great difficulties in cultivar management. In Portugal, several synonyms were confirmed by Lopes et al., (1999, 2006), namely: i) cultivar groups of 'Fernão Pires', from three geographic origins are identical to 'Maria Gomes'; ii) 'Castelão' cultivar is the same which 'Periquita', 'Castelão Francês', 'João Santarém' and 'Trincadeira'; III) 'Moscatel de Setúbal' and 'Muscat of Alexandria' are also synonyms, IV) 'Malvasia Fina' cultivar is the same as 'Assario', 'Boal' from Madeira Island and 'Boal Cachudo', V) 'Sercial' grown in Madeira island is the same which 'Esgana Cão', VI) 'Gouveio' and 'Gouveio Roxo' showed the same allelic profile as 'Verdelho' grown in the Dão region, and VII) 'Verdelho' from Island Madeira and Azores are also synonyms.

An Iberian example of synonyms is the cultivar 'Aragonez', known as 'Tinta Roriz' in the Douro and 'Tempranillo' in Spain (Eiras Dias et al., 2011; Ibáñez et al., 2012). Another example is the cultivar 'Grenache' in France, known as 'Garnacha Tinta' in Spain, 'Cannonau' in Sardinia and 'Red Tokai' in the Italian peninsula. Many other examples may be found all over the world (Calo et al., 1990). Grando et al., (2000) identified 11 cases of synonyms within cultivars grown in the Trentino area in Northern Italy using 7 microsatellite (SSR) loci. Cases of false synonymy or homonymy may also be found in many historically grapevine growing areas. An example is the variety 'Limnio' also known as 'Limniona', cultivated mainly in the Greek Aegean islands that differs from the variety 'Limniona' also known as 'Limnio' mainly cultivated in Thessaly (Stavrakas, 2011).

The correct identification of the different cultivars is important in order to optimize cultivation practices and wine authenticity. The traditional ampelographic methods tend to be inconvenient as they require an expert in classic ampelography (morphologic and ampelometric identification in field conditions) able to perform a rigorous monitoring during vegetative growth cycle. However, these phenotypic characteristics are often influenced by nutritional and phytosanitary status and by environmental conditions. These reasons led to the development and use of molecular methods for cultivar identification and certification. The International Organization of Vine and Wine (OIV) suggested the use of 6 SSR loci as a reference for the genetic identity of cultivars (OIV, 2009).
In this study a set of 19 microsatellite loci were used, which includes only four of the OIV above mentioned along with other 15 previously described in Laucou at al. (2011), which are very polymorphic and are scattered in eighteen out of nineteen linkage groups in Vitis. The discriminatory ability of these 19 SSR markers will be used in the present work to differentiate grapevine cultivars and/or clones, and will be used in the future on phylogeny and genetic diversity studies. The objective of this study was to genotype minor cultivars from Portugal (19 accessions), as well as, accessions collected in France (4), Spain (4) and Greece (1), kept at the Portuguese National Ampelographic Collection (CAN, international code PRT051). Some of these accessions have never been genotyped, given that they are local and underused cultivars, not used today in the wine industry. Identifying synonyms in minority cultivars increases the possibility of obtaining adequate plant material for certification purposes and for commercialization.

\section{MATERIAL AND METHODS}

\section{Plant Material}

Cultivars to be genotyped are maintained in the Portuguese Ampelographic Collection (CAN) for the last 20 years and were originally collected in germplasm banks from France, Spain and Portugal. CAN was established in 1988 at INIAV-Dois Portos, $60 \mathrm{Km}$ north of Lisbon and is the international reference for the Vitis genus in Portugal (reference PRT 051).

The twenty eight accessions used in this study are listed in Table I. Several of the Portuguese cultivars are known to be old cultivars, close to extinction, with some of them kept only at CAN. These cultivars were introduced in the collection as a result of intense prospection in all the Portuguese wine regions, including the Azores and Madeira insular regions. The Spanish (4), French (4) and Greek (1) cultivars were used in this study because some of them have Portuguese names and/or because they show morphologic similarities to Portuguese cultivars (see in Table I and Supplemental Table I, groups of cultivars that previous morphologic data suggest the existence of synonyms). The cultivars Riesling, Touriga Nacional and Cinsaut were used as controls while inter-specific hybrid Barco do Porto and Vitis aestivalis were used as out-groups (Table I).

When possible, cultivars are identified according the prime name and variety number (Table II) proposed by the Vitis International Variety Catalogue (VIVC, www.vivc.de). 
Table I

List of plant material used in this study

Lista do material vegetal utilizado no presente estudo

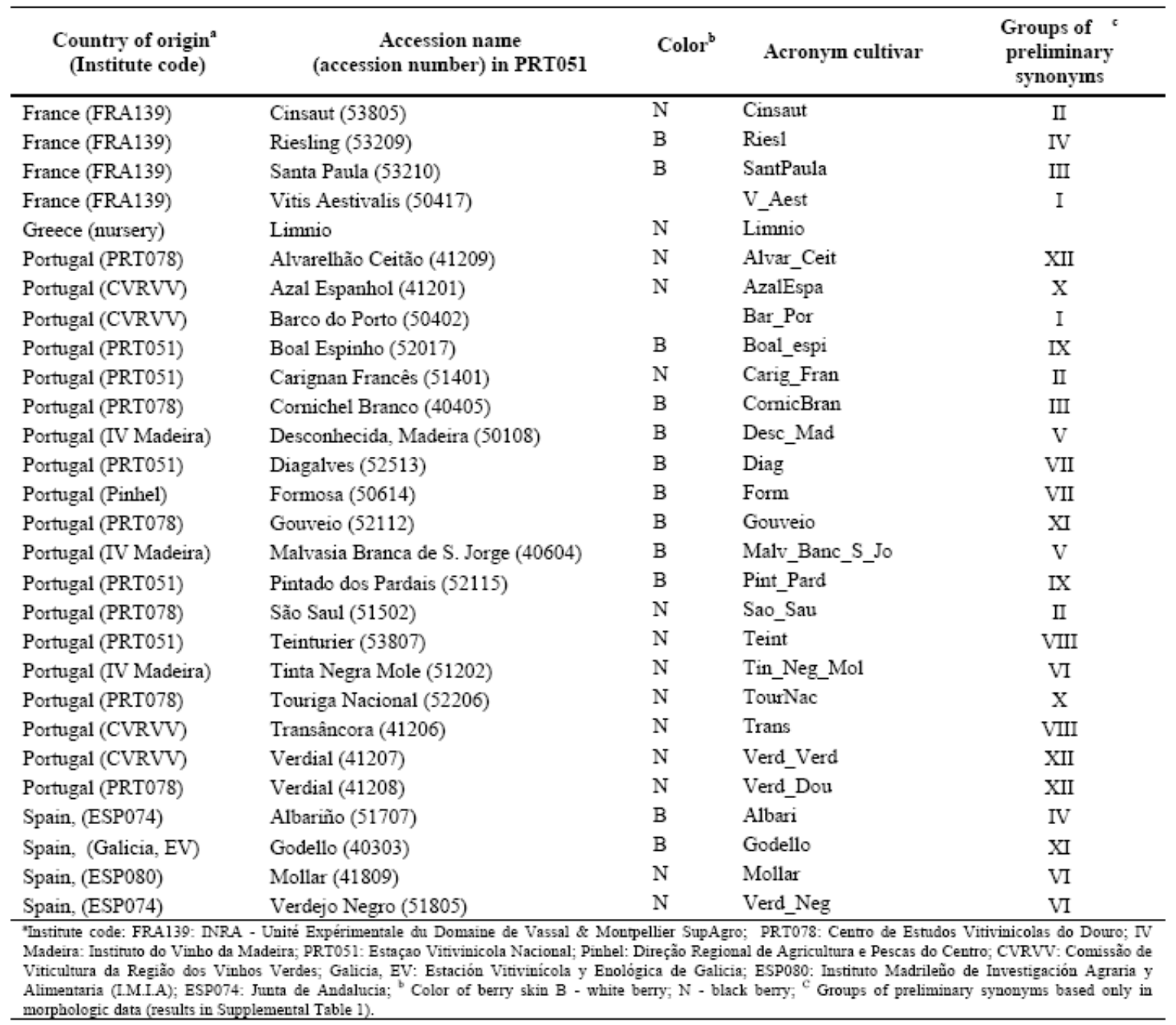

\section{DNA Extraction and PCR Amplification}

Genomic DNA was isolated from young leaves according to the protocol suggested by Lodhi et al., (1994) in order to minimize the effect of contaminants such as polyphenols and polysaccharides. Harvesting yields of DNA ranged from 30 to $150 \mathrm{ng} / \mu \mathrm{L}$ and all samples were diluted to an adequate concentration (10 to $20 \mathrm{ng} / \mu \mathrm{L}$ ). Nineteen nuclear microsatellites were divided into 6 multiplex mixes (Mplex1 SSRs:

VVMD27, VVMD25, VVMD28 and VVMD32; Mplex2 SSRs: VVMD5, VVMD7 and VVS2; Mplex3 SSRs: VMC4f3 and VVMD24; Mplex4 SSRs: VVIb01, VVIn73, VVIh54 and VVIq52; Mplex5 SSRs: VVIp31, VVIp60 and VVMD21; Mplex6 SSRs: VMC1b11, VVIn16 and VVIv67. One primer of each pair was previously labeled with fluorescent Dye (blue or green or black). Each multiplex reaction was prepared according to the manufacturer's instructions of Maxima Hot Start PCR Master Mix (2x).

The Biometra T-Gradient Thermoblock thermocycler was programmed to $15 \mathrm{~min}$ at $94{ }^{\circ} \mathrm{C}$, followed by 30 sec at $94{ }^{\circ} \mathrm{C}, 90 \mathrm{sec}$ at $56{ }^{\circ} \mathrm{C}, 60 \mathrm{sec}$ at $72{ }^{\circ} \mathrm{C}$ and a final extension step of $30 \mathrm{~min}$ at $72{ }^{\circ} \mathrm{C}$. After verifying the PCR products using gel electrophoresis, capillary electrophoresis was carried out in the automatic sequencer CEQ 8000 Genetic Analysis System (Beckman Coulter). DNA size standard-400 (P/N 608109) was included as an internal sizing standard and labeled products were analysed and sized using the CEQ System (version 9) software. 


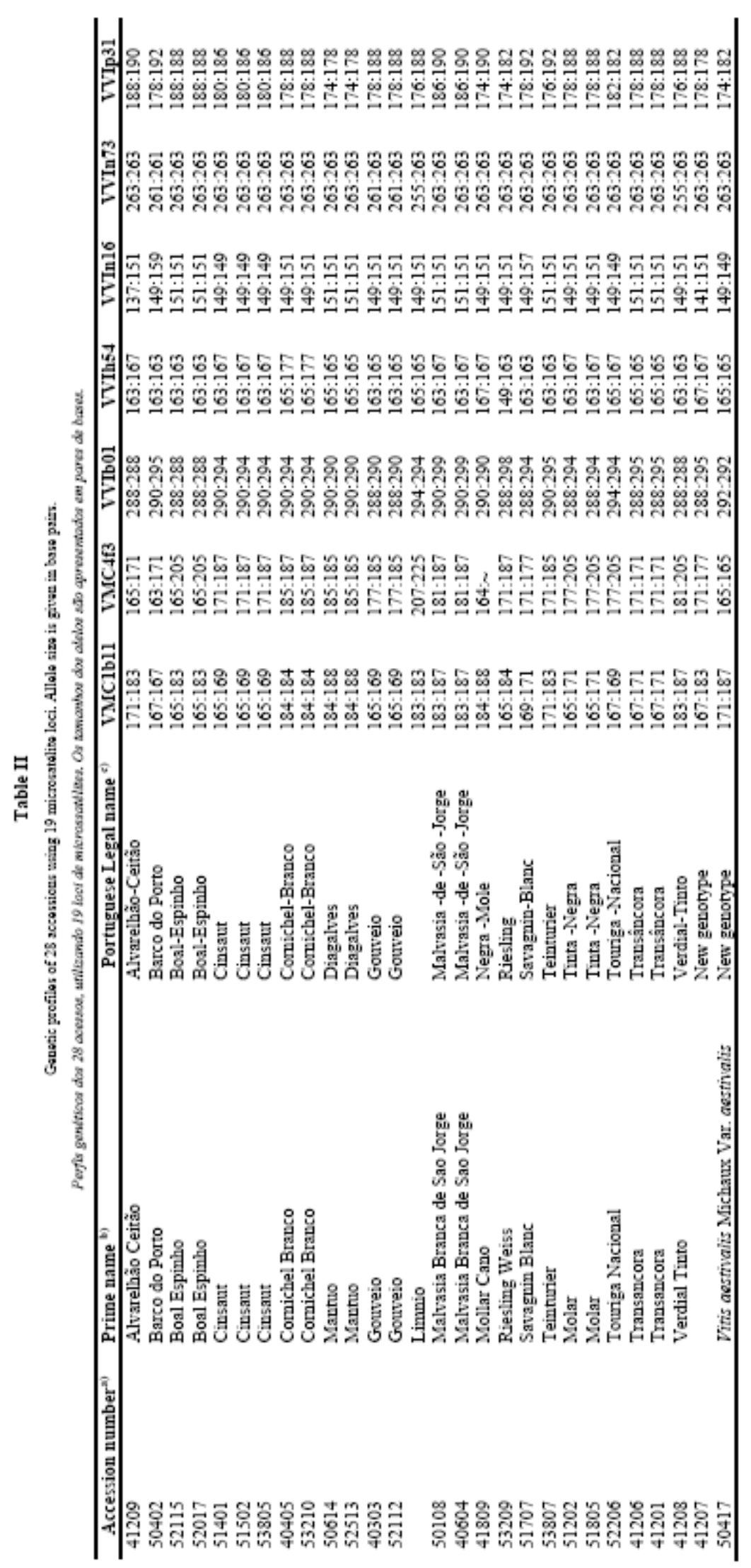




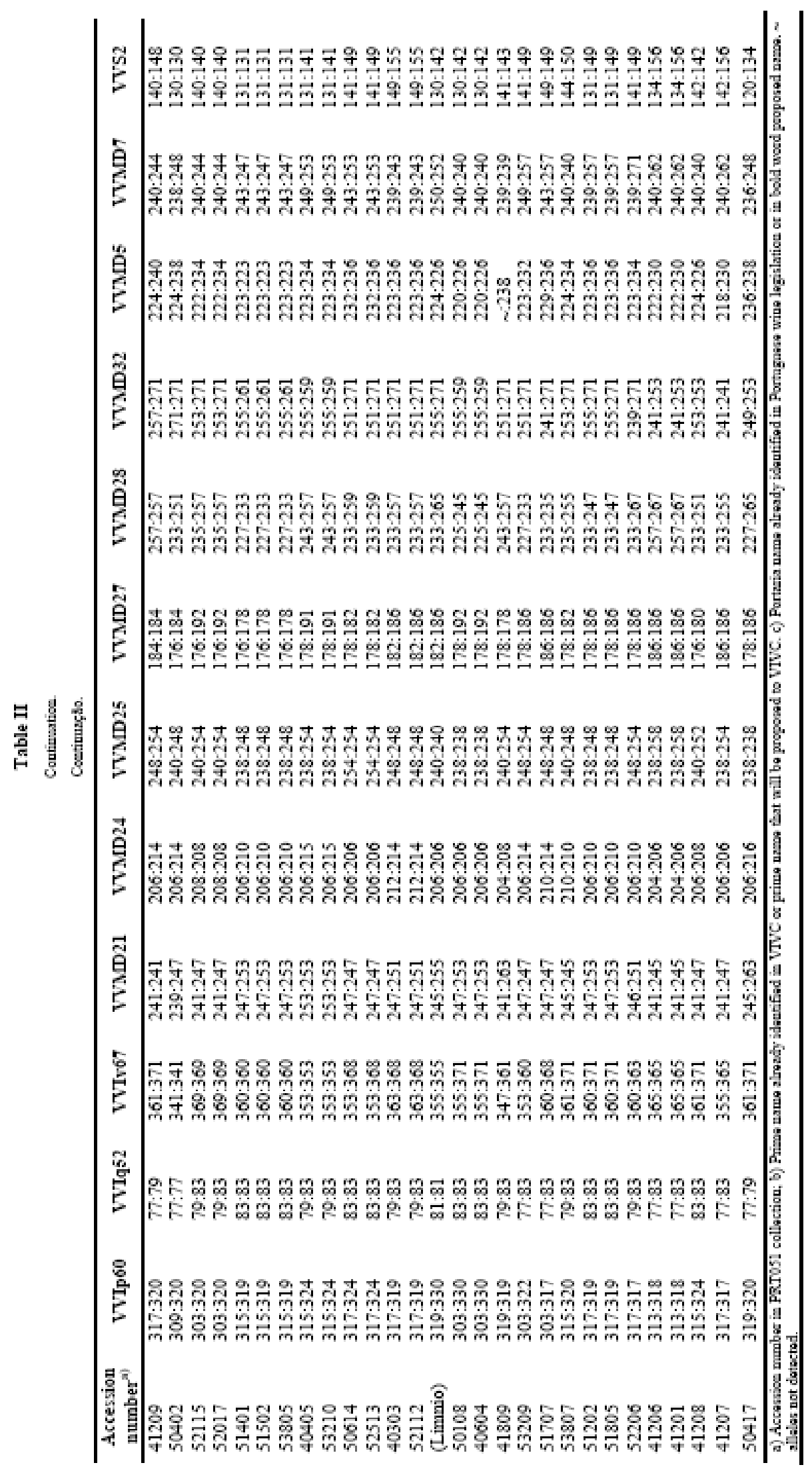




\section{Phenetic relationships}

The genetic distance among cultivars was calculated using the software GenAlex 6.501 (Peakall and Smouse, 2012), while MEGA 5.2 (Tamura et al., 2011) was used to construct the phenetic tree based on the unweighted pair-group arithmetic average method (UPGMA) over a matrix of genetic distances obtained with the simple match algorithm. The Excel Microsatellite Toolkit software (Park, 2001) was used to identify the matches with cultivars genotyped by Lacombe et al. (2013).

Results obtained by Veloso et al. (2010) and Santiago et al. (2007) were also used to compare genotyped cultivars (these comparative analyses were examined only in common locus).

\section{RESULTS AND DISCUSSION}

\section{Phenotype accessions and true genetic identity}

A morphological characterization of the 28 accessions under study, based on the OIV descriptors was made (Supplemental Table I). This characterization allowed the formation of 12 groups of potential synonyms (see Table I, last column and Supplemental Table I): I) Vitis Aestivalis/ Barco do Porto; II) Cinsaut/São Saul/Carignan Francês; III) Santa Paula/Cornichel Branco; IV) Riesling/Albariño; V) Malvasia Branca de São Jorge/Desconhecida da Madeira; VI) Tinta Negra Mole/Mollar/Verdejo Negro; VII) Diagalves/Formosa; VIII) Teinturier/Transâncora; IX) Pintado dos Pardais/Boal Espinho; X) Azal Espanhol/Touriga Nacional; XI) Gouveio/Godello; XII) Verdial 41208/Alvarelhão Ceitão/Verdial_41207). The Greek cultivar Limnio when compared with the other accessions formed an out-group.

Amplification of 19 SSRs on the 28 accessions produced twenty different genotypes (Figure 1). Relative allele sizes were standardized using three reference cultivars (Touriga Nacional, Cinsaut and Riesling) common to the data obtained by Lacombe et al. (2013). Data was analyzed with Excel Microsatellite Toolkit software (Park, 2001) and ten matching genotypes were detected between the 28 accessions and the accessions genotyped by Lacombe et al. (2013): Touriga Nacional/Touriga Nacional (\#1493); Santa Paula/Santa Paula (\#701); Riesling/Riesling(\#274); Cinsaut/Cinsaut (\#5); Gouveio/Gouveio (Verdelho) (\#296); Teinturier/Teinturier (\#303); Diagalves/Diagalves (\#1536); Tinta Negra Mole/Tinta Madeira (\#1529); Albariño/Savagnin $=$ Traminer (\#257) and
Mollar/Mollar (\#1471). From these 10 matches only the CAN accession Albariño (51707), originated from ESP74 (Junta de Andalucia), is clearly misidentified in the CAN.

\section{Historical remarks from cultivars identified as synonyms and homonyms}

The genetic relationships among the 28 accessions are shown in the phenogram derived from SSR data (Figure 1). In this phenogram eight cases of synonymy and one case of homonymy were identified. The synonymous found are: i) São Saul (51502), Cinsaut (53805) and Carignan Francês (51401); ii) Tinta Negra (51202) and Verdejo Negro (51805); iii) Godello (40303) and Gouveio (52112); iv) Cornichel Branco (40405) and Santa Paula (53210); v) Formosa (50614) and Diagalves (52513); vi) Transâncora (41206) and Azal Espanhol (41201); vii) Pintado dos Pardais (52115) and Boal Espinho (52017); viii) Desconhecida da Madeira (50108) and Malvasia Branca de S. Jorge (40604).

The comparison of the genotypes show that Carignan Francês (51401) and São Saul (51502) are synonyms of Cinsaut (53805), as already expected from the comparison of the morphological descriptors recommended by OIV (OIV, 2009). The cultivar Carignan Francês (51401) was wrongly considered in Portugal as synonymy of Carignan Noir. The Vitis International Variety Catalogue does not include Carignan Francês (51401) as synonym of Cinsaut, but as synonym of Carignan Noir. ViVC should correct this synonymy and consider Carignan Francês as synonymous of Cinsaut and not of Carignan Noir.

Tinta Negra Mole (51202) or Tinta de Madeira and Verdejo Negro (51805) are synonyms (Table I and II), as showed by the morphologic descriptors of both accessions (Supplemental Table I). Comparison of our results with the VIVC (Molar, prime name and $\mathrm{n}^{\circ}$ 15678) and with results from Ibáñez et al. (2003) confirmed that these cultivars are synonyms. In the Madeira Island Tinta Negra Mole is the most widely planted cultivar. In the Azores Islands Tinta Negra Mole is grown under the name of Saborinho. Tinta Negra Mole is identified as Tinta Negra in the Portuguese law that established the cultivars legally accepted to produce wine in the country (Portaria $n^{\circ}$ 380/2012 de 22 de Novembro), and, in Mainland Portugal, is found in vineyards at Colares and Pinhel under the designations of Molar and Rabo de Ovelha Tinto, respectively. Tinta Negra Mole is different from Negra Mole (52202) cultivated in the Algarve region (unpublished results). The comparison of our results with those obtained by Veloso et al. (2010) 
shows that cultivars Mollar (41809) from Spain and Negra Mole from Algarve are synonyms. Lacombe et al. (2013) also identified this clear synonym (Negra
Mole $=$ Mollar_\#1471) and VIVC include these two names as synonyms of Mollar Cano (VIVC n ${ }^{\circ} 7901$ ) as prime name.

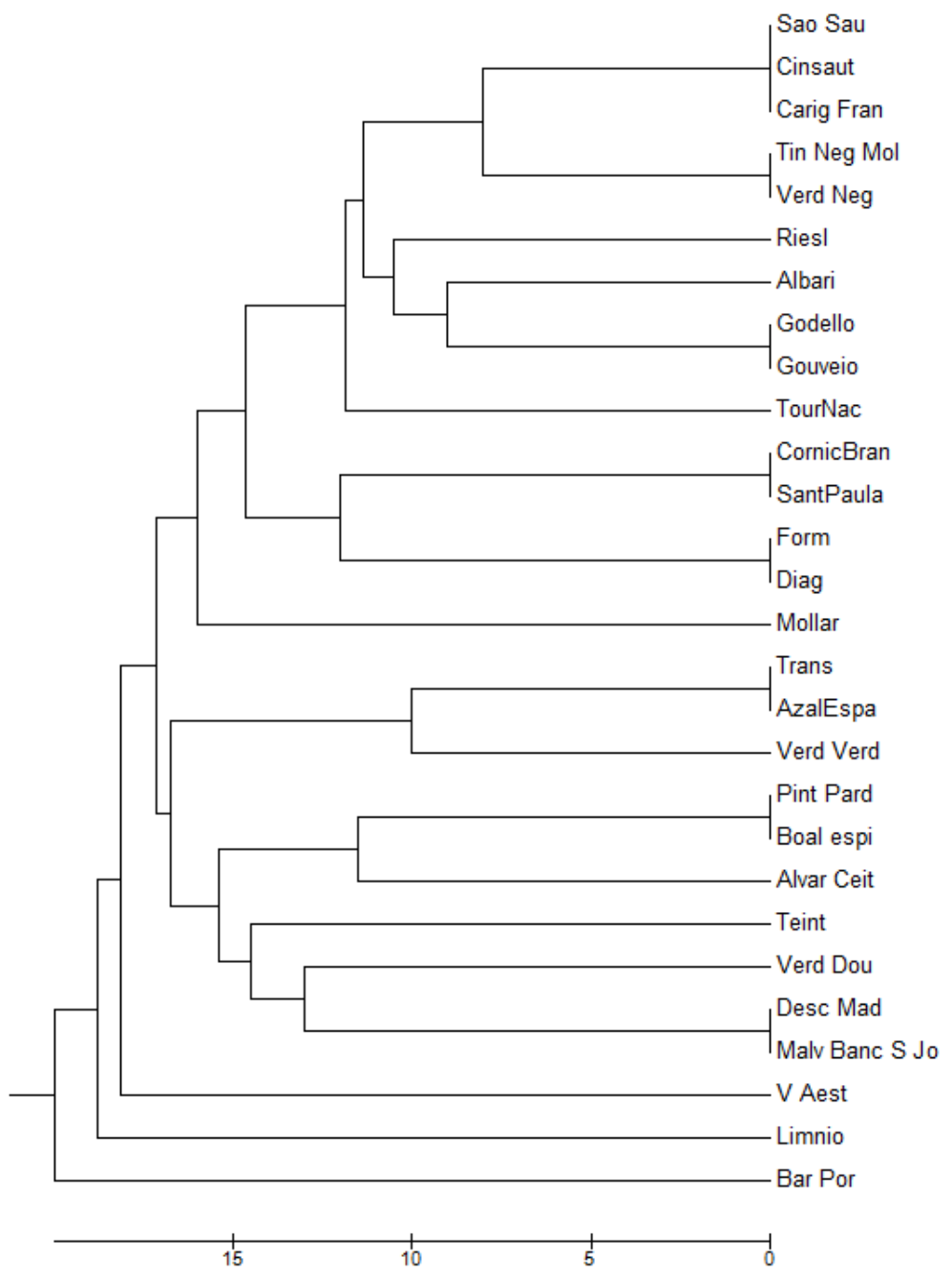

Figure 1. Phenogram of the genotyped cultivars using the simple match algorithm as coefficient of distance, and UPGMA as the clustering method.

Fenograma das cultivares genotipadas usando o algoritmo de correspondência simples como coeficiente de distância, e o método de agrupamento UPGMA

The synonymies between the cultivars Godello (40303)/Gouveio (52112); and Diagalves (52513)/Formosa (50614) have been already described on European Vitis Database (http://www.eu-vitis.de/index.php).

Cornichel Branco (40405) and Santa Paula (53210) are synonyms and neither is cited in ancient Portuguese bibliography, and thus possibly a recent genotype in the Portuguese germplasm. The VIVC database includes these two cultivars as distinct
(Cornichel Branco, VIVC n 17666 and Santa Paula, VIVC no 23941). No new plantations are known with Cornichel Branco/Santa Paula in Portugal. In Portugal, all existing genotypes of this minor cultivar are restricted to the CAN, but are also preserved in France, INRA (FRA139).

The cultivar Transâncora (41206) and Azal Espanhol (41201) both from Vinhos Verdes provenance are new synonyms identified in this work. These cultivars are almost extinct, since no new vineyards planted 
recently are known. A VIVC database refers Azal Espanhol (VIVC no 23978) and Transâncora (VIVC $\mathrm{n}^{\mathrm{o}}$ 17734) as different cultivars without a prime name attributed. In the old Portuguese written records the cultivar Azal or Azar is the name of several black berry cultivars ("Azal", Azal Preto, Azal Azedo, Azal Fechado or Azar Hespanhol) that were different from "Traz de Âncora" (Menezes, 1900), which may be the origin of the name Transâncora. The only relations between these two cultivars are the color of the berries and the wine region of origin (Vinhos Verdes) were they were both cultivated. In the actual Portuguese legislation only the name Transâncora is mentioned.

Pintado dos Pardais (52115) / Boal Espinho (52017) are synonyms as previously proved using only morphologic data (Eiras Dias et al., 2011). The VIVC does not include Pintado dos Pardais as synonym of Boal Espinho.

Desconhecida da Madeira (50108) and Malvasia Branca de S. Jorge (40604) were identified as synonyms corroborating the morphological data obtained at the CAN (Supplemental Table I). This cultivar is grown only in Madeira Island and is different from Malvasia Candida also cultivated in Madeira Island. While Malvasia Branca de S. Jorge is used in the establishment of new vineyards in Madeira Island (only standardized plant material).

The CAN accession Albariño (51707) is misidentified. The comparison of our data with the data of Lacombe et al. (2013), of Veloso et al. (2010) and of Santiago et al. (2007) revealed that the correct identification of this accession is Savagnin Blanc. Albariño is the Spanish cultivar synonym of the Portuguese cultivar Alvarinho (52007), native to northwest of the Iberian Peninsula abundantly grown in the Minho in Portugal and Galicia in Spain.

Verdial N (41208) cultivated in Douro and Verdial (41207) cultivated in Vinhos Verdes regions are homonymous (Figure 1, Table I). In these cases new surveys will be needed to clarity their situation to be able to assign appropriate names to each of these cultivars.

Others homonymies between the cultivars: i) Azal Espanhol (41201) and Azal (VIVC $\mathrm{n}^{\circ} 815$ that correspond to 52809 of CAN), ii) Alvarelhão Ceitão (41209) and Alvarelhão (VIVC $\mathrm{n}^{\circ} 1650$ that correspond to 53207), iii) Tinta Negra (51202) and Negra Mole (prime name Mollar Cano, VIVC n 7901 and correspond to 52202 of CAN), iv) Albariño B (51707) and Alvarinho (VIVC $\mathrm{n}^{\circ} 15689$ and correspond to 52007 of CAN) were confirmed, as expected from the morphologic data and the analyses of the SSR profiles and comparing with the VIVC.

The comparison of our results with the results of Lacombe et al. (2013) also show that the Italian cultivar with prime name Formosa on VIVC (Pirovano 245 \#1015 in Lacombe et al., 2013), is an homonym of the Portuguese cultivar Formosa.

The cultivar Limnio is often confused with the cultivar Limniona, which genetic profile was included in the Greek Vitis database by Lefort and RoubelakisAngelakis, (2001). The Vitis International Variety Catalogue (VIVC) includes two Limniona cultivars as homonyms. The accession used in this study has the same SSR profile of the cultivar Limnio (prime name, $n^{\circ}$ 6835) entered in the VIVC database. This accession is now well identified and can be marketed under the name Limnio by the plant nursery who supplied this material. The genetic profile of cultivar Limnio is clearly different from the Portuguese cultivars analyzed in this study.

The phenetic analysis (Figure 1) show that all the Portuguese cultivars, apart from Barco do Porto (50402), are clustered into two sub groups that differentiate from Vitis aestivalis (50417) and the Greek cultivar Limnio. Although there is only one Greek cultivar in this study, this clustering seems to discriminate between "proles occidentalis", that should contain the Portuguese cultivars and "proles pontica", which should include the cultivar Limnio, in agreement with the division by ecotypes proposed by Negrul (1938). Barco de Portugal (50402) is thought to be an inter-specific hybrid.

Identifying synonyms in minority cultivars increases the possibility of obtaining adequate plant material for certification purposes and commercialization. For that purpose, the 19 SSR loci profiles will be added to the Portuguese genotyping database (Veloso et al., 2010) in order to optimize the management of the CAN and to clarify possible existing confusions. This information will be also disclosed to the Vitis International Variety Catalogue (http://www.vivc.de/).

\section{CONCLUSIONS}

Genotyping of 28 grapevine accessions using 19 SSR loci revealed eight cases of synonymy, one case of homonymy and one case of mislabeling. Eight of these cultivars (Alvarelhão Ceitão, Boal Espinho, Cornichel Branco, Malvasia Branca de S. Jorge, Molar, Transâncora, Verdial from Vinhos Verdes and Verdial from Douro) are minor cultivars, with no certified plant material. The correct identity and the 
detection of synonyms are fundamental for future plant material certification and commercialization, as well as to the knowledge of the diversity of the accessions to be managed and maintained. The intense search of synonyms in minor cultivars increases the possibility of finding plant material in conditions to be candidate for certification control.

Further analysis of the genetic identity of grapevine cultivars is needed in order to optimize the management of the Portuguese National Ampelographic Collection. The obtained information will be proposed to be added to the Portuguese legislation of the grapevine cultivars suited for wine production.

\section{ACKNOWLEDGMENTS}

Antonios Alifragkis would like to thank the Alexander S. Onassis Public Benefit Foundation which supported him with a scholarship for the completion of the M.Sc studies. Jorge Cunha is funded by "Fundação para a Ciência e Tecnologia" (SFRH/BPD/74895/2010). This study was carried out in the framework of the European research projects: i) GrapeGen06 "Management \& Conservation of Grapevine Genetic Resources" and ii) COST Action FA1003 "East-West Collaboration for Grapevine Diversity Exploration and Mobilization of Adaptive Traits for Breeding". Margarida Teixeira-Santos is thanked for helping with the English version of the manuscript.

\section{REFERENCES}

Calo A., Costacurta A., Cancellier S., Forti R., 1990. Garnacha, Grenache, Cannonao, Red Tokai, a unique grapevine. Vingevini, 17, $45-48$

Eiras-Dias J.E., Faustino R., Clímaco P., Fernandes P., Cruz A., Cunha J., Veloso M., Castro R., 2011. Catálogo das castas para vinho cultivadas em Portugal - Volume I. Instituto da Vinha e do Vinho I.P., Chaves Ferreira - Publicações SA.

Grando M.S., Frisinghelli C., Stefanini M., 2000. Genotyping of local grapevine germplasm. Acta Hort., 528, 183-187.

Ibáñez J., De Andrés M.T., Molino A., Borrego J., 2003. Genetic study of key spanish grapevine varieties using microsatellite analysis. Am. J. Enol. Vitic., 54, 22-30.

Ibañez J., Muñoz-Organero G., Zinelabidine L.H., De Andrés M.T., Cabello F., Martíñez-Zapater J.M., 2012. Genetic origin of the grapevine cultivar Tempranillo. Am. J. Enol. Vitic., 63, 549-553.

Lacombe T., Boursiquot J.-M., Laucou V., Vecchi-Staraz M., Péros J.-P., This P., 2013. Large-scale parentage analysis in an extended set of grapevine cultivars (Vitis vinifera L.). Theor. Appl. Gene., 114 .

Laucou V., Lacombe T., Dechesne F., Siret R., Bruno J.P., Dessup M., Dessup T., Ortigosa P., Parra P., Roux C., Santoni S., Varès D., Péros J.P., Boursiquot J.M., This P., 2011. High throughput analysis of grape genetic diversity as a tool for germplasm collection management. Theor. Appl. Gene., 122, 1233-1245.

Lefort F., Roubelakis-Angelakis K., 2001. Genetic Comparison of Greek Cultivars of Vitis vinifera L. by Nuclear Microsatellite Profiling. Am. J. Enol. Vitic., 52, 101-108.

Lodhi M.A., Ye G.-N., Weeden N.F., Reisch B.I., 1994. A simple and efficient method for DNA extraction from grapevine cultivars and Vitis species. Plant. Mol. Biol. Rep., 12, 6-13.

Lopes M.S., Santos M.R., Eiras-Dias J.E., Mendonça D., Câmara Machado A., 2006. Discrimination of Portuguese grapevines based on microsatellite markers. J. Biotechnol., 127, 34-44.

Lopes M.S., Sefc K.M., Eiras-Dias E., Steinkellner H., Laimer Câmara Machado M., Câmara Machado A., 1999. The use of microsatellites for germplasm management in a Portuguese grapevine collection. Theor. Appl. Gene., 99, 733-739.

Menezes P., 1900. Apontamentos para o estudo da Ampelographia Portugueza. Boletim da Direcção Geral de Agricultura. Ministério das Obras Publicas. Comercio e Industria, Imprensa Nacional, Lisboa.

Negrul A.M., 1938. Evolution of cultivated forms of grapes. $C R$ Acad. Sci. USSR, 18, 585-588.

OIV, 2009. Descriptor list for grapevine varieties and Vitis species. Organisation Internationale de la Vigne et du Vin (OIV). 2nd edition. Paris, France.

Park S.D.E., 2001. Trypanotolerance in West african cattle and the population genetic effects of selection. University of Dublin, Dublin.

Peakall R., Smouse P.E., 2012. GenAlEx 6.5: genetic analysis in Excel. Population genetic software for teaching and research-an update. Bioinformatics, 28, 2537-2539.

Portaria $\mathrm{n}^{\mathrm{o}} 380 / 2012$, de 22 de Novembro, do Ministério da Agricultura, do Mar, do Ambiente e do Ordenamento do Território. Diário da República, 1. ${ }^{\mathrm{a}}$ série - N. ${ }^{\circ} 226$. Lisboa, Portugal.

Santiago J.L., Boso S., Gago P., Alonso-Villaverde V., Martínez M.C., 2007. Molecular and ampelographic characterisation of Vitis vinifera L. "Albariño", "Savagnin Blanc" and "Caíño Blanco" shows that they are different cultivars. Span. J. Agric. Res., 5, $333-$ 340 .

Stavrakas E.D., 2011. Ampelography. 624 p. Ziti publications, Thessaloniki.

Tamura K., Peterson D., Peterson N., Stecher G., Nei M., Kumar S., 2011. MEGA5: Molecular evolutionary genetics analysis using maximum likelihood, evolutionary distance, and maximum parsimony methods. Mol. Biol. Evol., 28, 2731-2739.

Veloso M.M., Almandanim M.C., Baleiras-Couto M., Pereira H.S., Carneiro L.C., Fevereiro P., Eiras-Dias J., 2010. Microsatellite database of grapevine (Vitis vinifera L.) cultivars used for wine production in Portugal. Ciência Tec. Vit., 25, 53-61.

Viala P., Vermorel V.,. 1901-10. Traite generale de viticulture. Ampelographie, 7 vols. 3146 p. Masson et Cie, Paris. 


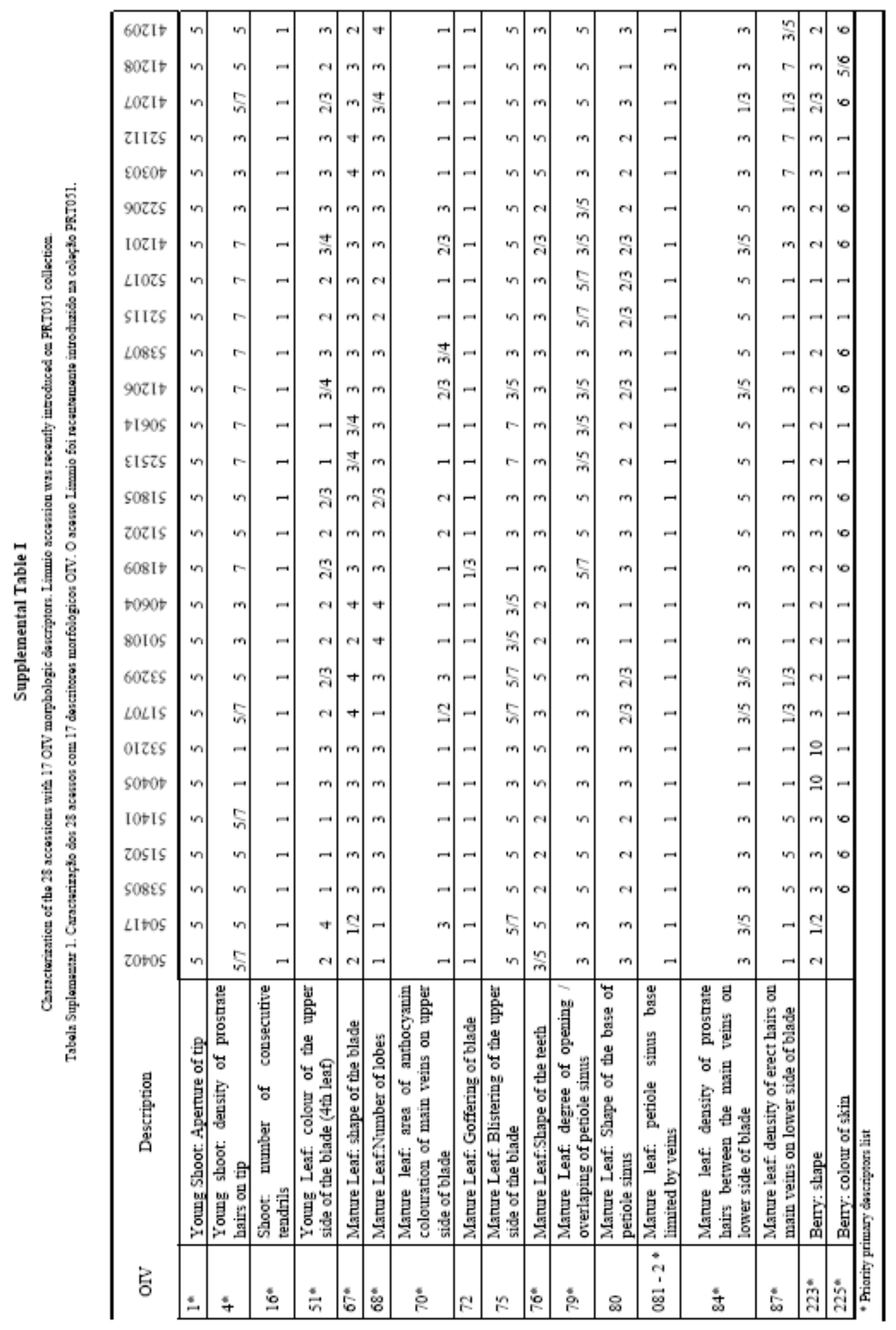

